sciendo Порівняльна професійна педагогіка 8(3)/2018

Comparative Professional Pedagogy 8(3)/2018

DOI: $10.2478 /$ rpp-2018-0040

$\mathrm{PhD}$ in Pedagogy, Associate Professor, VALENTYNA PLIUSHCH Volodymyr Vynnychenko Central Ukrainian State Pedagogical University Address: 1 Shevchenko S., Kropyvnytskyi, Kirovohrad Region, 25000, Ukraine E-mail: valentynapl@ukr.net

\title{
CONCEPTS OF TEACHER EDUCATION DEVELOPMENT IN EUROPE
}

\begin{abstract}
The article analyzes global trends in the development of teacher education with the aim to improve the education system in Ukraine and presents a comparative and pedagogical study on the concepts of teacher education development in Europe, in particular Great Britain and Germany. It was found that conceptual and methodological fundamentals of modern foreign pedagogy were constantly updated and adjusted. In West European pedagogy, the most common concepts of teacher education development are rationalistic, conservative and neohumanistic (phenomenological) ones. It was specified that rationalistic and traditional concepts of intellectual development were appropriate for the individuals who were reluctant to engage in cognitive activities and needed constant external stimuli. The phenomenological concept is humanistic-oriented and prioritizes personal learning targeted at individual selfrealization and defines a learning environment to be a unique catalyst for successful learning. In Great Britain and Germany, open learning is one of the leading forms in realizing the phenomenological concept. Theoretical principles of open learning are related to the philosophy of existentialism, which emphasizes the need to create relevant conditions for learning so that students may freely realize their individual needs. Despite the fact that the concept of open learning is still under development and primarily describes the basic guidelines for education development and the issue of its practical implementation has not beet fully disclosed yet, it appears as a fundamental strategy for modern education. The main principle of open learning is individualization of the education process. Individual skills of students determine the content, methods, forms and tools of learning since the pedagogy of modern teacher education in England is based on them. It was noted that the system of distance education in Ukraine was under development too. However, it may become rather promising provided that Ukrainian educators have taken into account positive aspects of relevant foreign experience and combined the most advanced distance learning technologies with the most effective technologies and methods of traditional classroom learning. West European experience in developing higher teacher education can be implemented in Ukraine provided that the most effective traditions of the national teacher education have been preserved and, therefore, can adjust them to the modern international standards.
\end{abstract}

Keywords: teacher education, development, concepts, West European pedagogy, Great Britain, Germany, open learning, distance education.

\section{INTRODUCTION}

Today Ukraine integrates into the European and global educational spaces and therefore aims to create a modern system of continuing education. In this regard, it is essential to set optimal goals and update the organization, content, models and methods of educational activities. When analyzing the position and a dynamic development of West European education systems one can conclude that this stage represents an era of a 
worldwide education reform. There appears to be an international unification of national educational standards, the expansion of educational models and the enhancement of current teaching technologies. In addition, every country intends to enrich its historically developed educational potential, for which reason it is important to critically study some innovative experience of other countries in organizing education and updating its content. As a result, it is necessary to analyze global trends in the development of teacher education with the aim to improve the education system in Ukraine.

Indeed, a comparative and pedagogical study on the systems of higher education in Great Britain and Germany which incorporate modern innovative systems of teacher training is rather relevant and is called for by the need to discover novel paradigms in professional training of teachers in the system of teacher education in Ukraine.

THE AIM OF THE STUDY

The aim of the study consists in conducting theoretical analysis on the concepts of teacher education development in Europe.

\section{THEORETICAL FRAMEWORK AND RESEARCH METHODS}

The intrinsic characteristics of education along with teacher training were analyzed by O. Fink (1978) (the basic issues of systematic pedagogy), A. Hargreaves (2000) (professionalism and professional learning), T. Herman (1977) (creating learning environments: the behaviced approach to education), R. Morshead (1975) (hidden idiologies in contemporary education), C. Patterson (1973) (humanistic education) et al. The issues of distance learning and open education development were outlined by many scholars including as T. Danylyshena (2008) (the development stages of distance education as an innovative form of the master training), Yu. Golionova (2009) (the importance of distance learning in the global educational space), M. Hanif, M. Nawaz and S. Tanyeer (1979) (the issues of open education) M. Leshchenko and A. Yatsyshyn (2014) (open education in the categorial dimension), I. Tavgen (2003) (the trends, policy and strategies for open and distance learning) et al.

While researching, such methods as analysis, synthesis, comparison, generalization were used to study scientific literature and compare the views of different scholars on the concepts of education.

\section{RESULTS}

Conceptual and methodological fundamentals of modern foreign pedagogy are constantly updated and adjusted. In West European pedagogy, the most common concepts of teacher education development are rationalistic, conservative and neohumanistic (phenomenological) ones.

P. Bloom, B. Skinner, E. Fink, the creators of rationalist education, emphasize the problem of knowledge acquisition and a practical adaptation of the youth to society by means of education. At the heart of the rationalist model ideology there is behavioural engineering founded by B. Skinner, according to which an individual can change his/her personality in one way or another, if using the right methods of influence and control (Fink, 1978). Rationalists believe that behaviour implies all kinds of reactions inherent in human beings, namely thoughts, feelings and actions. In Great Britain, the scholars following the rationalist conception of higher education development believe that the programme of professional teacher training should include relevant behavioural terms so that the teacher may effectively develop an appropriate behavioural repertoire of students and assess the obtained results.

Supporting the ideas of B. Skinner, T. Herman (1977) highlights the need for some greater clarity in the organization of the learning process, when teachers and students 
sciendo Порівняльна професійна педагогіка 8(3)/2018

Comparative Professional Pedagogy 8(3)/2018

clearly understand the goal of learning and, accordingly, what they must learn. As a result, the learning process is mechanically reduced to a set of certain behavioural units, that is, it is transformed into "some formalized training of externally manifested actions that are ranked according to the degree of their implementation complexity" (Herman, 1977).

The advantages of rationalist learning include the content characteristics of educational material, which depend on the current level of students' knowledge and skills; the absence of time limits for mastering the educational material. The disadvantage of behaviorist learning consists in a rather mechanical basis for developing cognitive structures of the individual and his/her cognitive potential. Thus, the rationalist concept of intellectual development is appropriate for the individuals who were reluctant to engage in cognitive activities and needed constant external stimuli.

The conservative concept is one of the leading concepts that have influenced the modeling of the education process in higher education institutions in Western Europe. The advocates of this theory insist on maintaining the conservative role of educational institutions and speak in favour of the proven methods and ways of organizing educational activities. They also believe that the learning process should be centered on one learner and therefore exclude any collective activities. The main role in the learning process is performed by the teacher who transfers knowledge and skills to students and is "a model or an ideal for which students must strive" (Morshead, 1975, p. 667).

The supporters of the phenomenological concept prioritize humanistic-oriented education and personal learning. The psychopedagogical theory of personality development in the education process is basically subjective and idealistic. This means that they explain the learning process based on the features of psychophysiological activity, its impact on the individual's development, his/her behaviour. The goal of teaching involves primarily the individual's self-realization and the lack of restrictions in his/her behaviour.

The scholars who follow the neohumanistic conception share the rationalists' view that learning should incorporate different activities and also contribute to greater emotional involvement of the students who "independently determine the goal of learning, take decisions about their actions, gain some valuable experience and are responsible for the consequences" (Hargreaves, 2000, pp. 151-182). Therefore, rationalists and traditionalists consider a cognitive component to be the main one in the organization of learning, whereas the supporters of the neohumanist concept prioritize cognition.

The main qualities of a professional teacher who adheres to the principles of humanism include the ability to provide the individual with the opportunity of selfrealization and revealing his/her true self. The priority is given to the teacher's role as an organizer of the learning process and a facilitator of students' socialization rather than a transmitter of information. According to R. Burns (1986), every teacher prioritizes those whom he/she teaches and only then, the goal of teaching.

Under today's conditions humanistic pedagogy is targeted at every child and has become the main theoretical basis for developing traditional teacher education in the West. The positive aspects of neohumanistic education are recognized by many scholars of Western Europe including L. Stenhouse, C. James, P. Ritter et al.

However, phenomenologists define a learning environment to be a unique catalyst for successful learning. In Great Britain and Germany, open learning is one of the leading forms in realizing the phenomenological concept of learning. Theoretical principles of open education are related to the philosophy of existentialism, which emphasizes the need to create relevant conditions for learning so that students may freely realize their individual 
needs. Currently, the definitions of the terms "openness" and "open education" in pedagogical theory and practice vary in terms of approaches (synergetic, anthropological, systemic ones) to revealing their essence. Despite the fact that the concept of open education is still under development and primarily describes the basic guidelines for education development and the issue of its practical implementation has not beet fully disclosed yet, it appears as a fundamental strategy for modern education. The phenomenon and the term "open learning" appeared in Great Britain in 1931. The main principle of open learning is individualization of the education process. Individual skills of students determine the content, methods, forms and tools of learning since the pedagogy of modern teacher education in England is based on them.

Under the present conditions, the concept of open education is associated with information technologies and distance education. Open learning and distance education are rapidly developing and their impact on the development of all education systems is greatly increased as information technologies evolve and improve.

Indeed, open learning and distance education increase not only the educational levels of society, but also contribute to improving qualifications and retraining of specialists in relation to the transition to new technologies. The main principle of open and distance learning is to provide more applicants with an access to education and professional training without limits in time and place (UNESCO, 2004, p. 13).

It should be noted that the technologies of open and distance learning in West European countries have been used since the 1960's. The first standards for implementing the methods of distance learning into higher education institutions were established by the Open University in Great Britain (Danylyshena, 2008, p. 47).

From the very beginning, the University has been successfully providing the forms of part-time and distance learning not only for British applicants but also for foreigners. The University is recognized as one of the largest higher education institutions in Europe and is one of the world leaders in open and distance learning not only in Great Britain but throughout Europe. In the early 21st century, the British system of education occupies the leading positions among other European countries in terms of distance learning availability. More than 1,300 British colleges and universities offer distance education. More than one million of European students engage in distance learning in Great Britain without leaving their country of residence (Golionova, 2009, pp. 20-24).

In Germany, the first university offering part-time education was founded in 1974 in Hagen and has been successfully implementing distance learning programmes for the past few decades (Schniders, 1997). The University of Hagen fits harmoniously with the German system of higher education and is rather popular among the adult population, who for some reason are not able to participate in conventional full-time education (Tavgen, 2003).

Already in the early 20th century, there appeared a large number of higher education institutions offering distance education in Germany. In the country, Virtuelle Fachhochschule or the Virual University of Applied Sciences offers full-fledged online courses. The German system of open and distance education as an alternative to conventional fulltime education is constantly improved.

Due to an active development of open education and distance learning in the late 20th century, many West European countries have defined the main objective of teacher education institutions to be relevant professional training of the future teachers who should strive for constant self-improvement, personal changes and be able to elaborate their teaching methodology, taking into account the changes in the content of education, learning and teaching technologies, as well as the development of the students themselves. 
sciendo Порівняльна професійна педагогіка 8(3)/2018

Comparative Professional Pedagogy 8(3)/2018

\section{CONCLUSIONS}

Therefore, the development of open learning and distance education in the late 20 th century - the eatly 21 st century has become the urgent need of the present, one of the ways to implement the concept of continuing education. In Ukraine, the system of distance learning is currently under development. In Ukraine in 2013, they issued the Decree on the Approval of Regulations on Distance Learning and since then the number of educational institutions, offices and centres for distance learning has been rapidly increasing. It should be noted that the development of distance education in Ukraine is primarily related to the introduction of blended learning. However, it may become rather promising provided the most advanced distance learning technologies have been combined with the most effective technologies and methods of traditional classroom learning.

West European experience in developing higher teacher education can be implemented in Ukraine provided that the most effective traditions of the national teacher education have been preserved and, therefore, can adjust them to the modern international standards.

Further researches should deal with theoretical analysis of such fundamental problems in Ukrainian higher teacher education as the development of goals, objectives, content, technologies, methods and techniques of distance education and self-development of future teachers based on the innovative ideas of European experience.

\section{REFERENCES}

1. Berns, R. (1986). Razvitie Ya-kontseptsii i vospitaniia. Moscow: Progress.

2. Danylyshena, T. (2008). Etapy stanovlennia dystantsiinoi osvity yak innovatsiinoi formy navchannia mahistriv. Visnyk Lvivskoho universytetu. Seriia: Pedahohichna, 24, 46-52.

3. Fink, E. (1978). Grundfragen der systematischen Pedagogik. Freiburg im Breisgau: Romback.

4. Golionova, Yu. A. (2009). Predposylki vozniknoveniia distantsionnogo obucheniia $\mathrm{v}$ mirovom obrazovatelnom prostranstve. Znanie, ponimanie, umenie, 2, 20-24.

5. Hanif, M., Nawaz, M., \& Tanyeer, S. (1979). Open education versus back to basics: an analysis of issues. Contemporary Education, 50 (2), 201-109.

6. Hargreaves, A. (2000). Four ages of professionalism and professional learning. Teachers and Teaching: History and Practice, 6 (2), 151-182

7. Herman, T. M. (1977). Creating learning environments: the behaviced approach to education. Boston, MA: Allynand Bacon.

8. Leshchenko, M. P., \& Yatsyshyn, A. V. (2014). Vidkryta osvita u katehorialnomu poli vitchyznianykh i zarubizhnykh uchenykh. Informatsiini tekhnolohii $i$ zasoby navchannia, 39 (1), 1-16.

9. Morshead, R. W. (1975). The clash of hidden idiologies in contemporary education. School Review, 83 (4), 663-675.

10. Patterson, C. H. (1973). Humanistic education. Englewood Clifis, NJ: Prentice Hall.

11. Schniders, I. (1997). Zaochnyi universitet v Khangene, Germaniia. Otkrytoe obrazovanie, 1. Vziato s http://www.e-joe.ru/sod/sod_97_1.html.

12. Tavgen, I. A. (2003). Distantsionnoe obuchenie: opyt, problemy, perspektivy. Minsk: BGU

13. The Open University. (2018). Retrieved from http://www.open ac.uk.

14. UNESCO. (2002). Open and distance learning. Trends, policy and strategy considerations. Retrieved from http://unesdoc.unesco.org/images/0012/001284/128463e.pdf.

15. Virtuelle Fachhochschule. (2018). Retrieved from https://www.vfh.de/=search. 